\title{
Perspectives and Empirical Study of Engineering College Students towards Entrepreneurship
}

\author{
J. Jose Prabhu \\ Independent Researcher and Visiting Professor, Department of Management, Management and Engineering \\ Colleges, Tamil Nadu, India \\ drjose999@gmail.com
}

\begin{abstract}
India experiences large troubles with its high degrees of joblessness amongst the youth particularly college finishes as an outcome of the absence of work experience, lowered abilities base, along college. The major issue managed in our financial scenario is the price, the price is high in India contrasted to all different various other nations, most of the graduates are currently unemployed or else operating in a business which not connected to their core. The emphasis of the study gets on just exactly how the way of thinking differs from a bachelor to an added on the appeal of entrepreneurship as work as well as to research the collaboration in between the business viewpoint along with the business opportunitiesentrepreneurial ambiance. The researcher applied a detailed study layout, as well as the populace of the study, is an engineering university student examining in design universities associated with Anna University. A checklist of colleges offering a Design Program in the Pudukottai district connected to Anna University was obtained from the Anna College site. The sample design taken on for the study is organized random sampling with a total sample size of 400 . The findings of the research study discloses that aspects towards entrepreneurship considerably affect the overall parental aspects of attitudes towards entrepreneurship.
\end{abstract}

Keywords

entrepreneurial opportunities, entrepreneurial attitudes, entrepreneurial environment; parental factors, parents occupation and guidance; business support fromparents

\section{Introduction}

Entrepreneurship plays an important role in economic prosperity and social stability in lots of established nations. India faces enormous difficulties with its high degrees of joblessness amongst the youth particularly college graduates due to lack of job experience, low abilities base and education (Modi, 2017). The Prime Minister interacted with Youthful Business owners at the "Champions of Change" effort organized by NITI Aayog at Pravasi Bharatiya Kendra, where 6 teams of Youthful Entrepreneurs made discussions prior to the PM on themes such as - Soft Power: Amazing India 2.0; Education And Learning and also Ability Advancement; Wellness and Nourishment; Invigorating a sustainable tomorrow; and Digital India; Today entrepreneurship is supplied in the majority of the universities as part of the curriculum yet it is evident that degrees of entrepreneurship are still not enhancing in the nation (Herrington et al., 2009), The Government currently likewise requires to play their component in motivating this development as well as provide chances for not simply education routed in the direction of structure business abilities however also passing positive plans/policies to enhance the business ecosystem in the nation (Chowdhry, 2015). 


\subsection{Problem Statement}

The primary trouble faced in our economy is Unemployment price, the price of unemployment is high in India compared to all other countries, most of the grads are now unemployed or else working in a business which not connected to their core This is mostly due to the fact that to the lack of understanding of the perspectives and understandings among the youth towards entrepreneurship, no coincidence that lots of universities are located in Tamilnadu, and also they have knowledgeable labors in a number of big sectors, The main problem is no recognition and extremely less understanding regarding the joblessness. Comprehending the factors that predict a business perspective is crucial due to the fact that entrepreneurial behavior is a result of the positive perspective formation and also the purpose. Those are self-discipline, steadfast, and also consistent, they are able to devote and recommit promptly, and they are not frightened by challenges (Timmons \& Spinelli, 2015). One of the crucial findings of the Worldwide Entrepreneurship Monitor Report of 2015 is exactly how perspectives differ from one individual to an additional the appearance of entrepreneurship as a job. The understanding of these attitudes can be critical in helping the policy instructions as well as in motivating entrepreneurship within the country (Bosma \& Levie, 2009).

\subsection{Objectives}

The objectives of the research are as follows:

- To understand the demographic profile of engineering college students.

- To study and analysis of parents occupation and business guidance from engineering students parents.

- To study the relationship between parental factors and entrepreneurial opportunities.

- To understand the relationship and behavior between parental factors and entrepreneurial environment within the engineering institution.

\section{Literature Review}

Daim et al., (2016) this research makes substantial payments to the understanding of entrepreneurial perceptions among students. Among the vital toughness of this research is that it is based upon a wide variety of information for pupils from 10 various countries. This paper discovers the variables influencing business behavior in order to recognize new instructional opportunities for its development, differences were discovered in between genders and countries on their perceptions of worth as well as expediency in the direction of business habits. One drawback of this research study could be the varying sample sizes from different nations. Extra well balanced example size from taken a look at nations would lead to more significant results.

Zhou (2012) The objective of the research study is that the entrepreneurship study of china is not much developed and they are in average common, their survey states that the majority of the college student pursue various other countries for the task as well as just a few of the trainees try to work in their country, the entrepreneurship education and learning can be established by taking disputes, study to the peoples, training to the educators, giving incentives to the teacher that focus on entrepreneurship education and likewise provide a fund to entrepreneurship education and learnings.

Muñoz-Bullón (2016) The main aim of the research is revealing the development of entrepreneurship over some decades and it is extremely interdisciplinary and heterogeneous as well as their institutions have actually arisen to provide even more technology and the entrepreneurship has arisen in a different location like universities, 
scientific research parks, incubators, commercial labs, and also college innovation transfer offices and also they likewise business agents, such as market and also scholastic researchers or business owners in firms or college.

Zaman (2013) this study adhered to the emotional attributes school of believed to research six entrepreneurial characteristics connected with entrepreneurship. The results of the t-test revealed that entrepreneurially inclined students are a lot more cutting-edge, prepared to take threats, very inspired, more self-assured, with the high inner locus of control but with regards to tolerance of ambiguity, there is no distinction in between inclined and also non-inclined students. The function of the research is to establish a nationwide degree point of view on business education to motivate colleges to use entrepreneurial training courses and also as major topics also.

Gibus el al. (2012) China's entrepreneurship education and learning is still in the early stage, as well as China lags behind the ordinary criterion of International Entrepreneurship Screen (TREASURE) in entrepreneurship education and learning. China today is not completely manipulating its business possibility, as well as improving this will certainly help the nation in additional changing its economic climate as well as attaining future economic as well as competitive toughness. Entrepreneurship education and learning in China will certainly benefit greatly from the combination of a more clear and more comprehensive significance of the principle, an informative and also visionary tactical structure at the national degree, an integrated educational program throughout the self-controls, an increased training program for the faculty, a closer web link in between the academy and also the industry, and a sound plan to tape the procedure and review the influence of entrepreneurship education and learning often.

Rengiah (2013) The conclusion and also findings of this research study has talked about the three research objectives developed for the research study in the context of the Malaysian colleges. The findings contribute to several of the concepts connected to both the mediating variables mindset towards objectives, family functions as well as business objectives. The functions of policymakers such as the universities, the federal government, SMEs, banks, moms, and dads as well as extended relative "contributions towards business objectives have been reviewed.

Thurik (2004) Government policy in the managed economy was mostly about control. Europe is bogged down in a stagnant economic growth as well as structurally high unemployment. Entrepreneurship is a critical aspect for accomplishing political objectives evaluated the European Council Satisfying at Lisbon.

Komulainen et al. (2014) The objective of the research is about in-service teachers involved with a discourse of external and also Interior entrepreneurship and also to produce relevant incorporations and exclusions and apply or test the objective pf business education and learning and also business people. The outcome of the research where the trainee encouraged towards interior entrepreneurship i.e. an enterprising mindset with attributes of self-responsibility, mindful and persistence as well as freedom.

Kuttim et al. (2014) this research discloses that the students in the efficiency-driven nations have a lot more possible entrepreneurship intents than the trainees in innovationdriven countries. They have a strong partnership with business activities. This study revealed the greater potential entrepreneurs remain in the efficiency-driven nations.

Basu (1999) this short article has to do with some of the successful business owners in India. This short article likewise provides suggestions categorically to the government, to the financial institutions as well as various other banks and also to the entrepreneurs. The support as well as the development of entrepreneurship culture ought to come to be the core part of our education system, to make sure that the boys, as well as women, can come 
to be "task providers" and not "task hunters". The government should supply reliable and also reliable consultancy solutions to the business owners. Application treatments, as well as authorization criteria, need to be made basic as well as fast lending approvals must be done at the branch level at the banks. Financial services should be offered close to business owners. Banks require to re-think concerning their loan providing policies to the entrepreneurs. The entrepreneurs ought to create a proper industrial plan prior to beginning a unit. Low levels of education and learning must not hinder one to start an industrial venture. Passions encourage guys. It activates men, expands their vision as well as make the life extra significant.

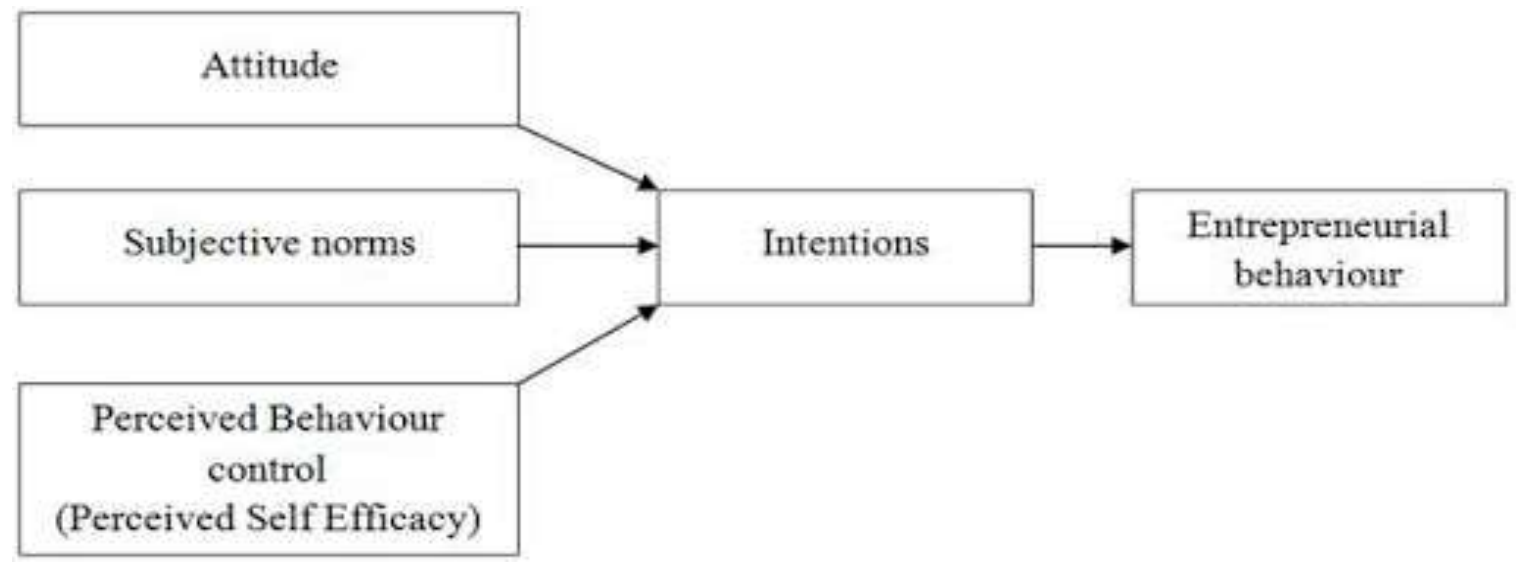

Figure 1. Conceptual Framework of Research

\section{Research Methodology}

The researcher applied descriptive research design and the population of the study is engineering college students studying in colleges affiliated to Anna University. List of colleges offering engineering Programme in Pudukottai district affiliated to Anna University was obtained from the Anna University website. The sample design adopted for the study is systematic random sampling with a total sample size of 400 using scientific formula and 40 respondents from each Institutions of 10 institutions offering MBA programme affiliated to Anna University. The pilot study with 30 samples pretested for questionnaire refinement. The reliability and content validity tested for the questionnaire. The primary data were collected using a structured questionnaire and the questionnaire was self-administered. Statistical tools used for the analysis is frequency analysis ,Anova and Multiple regression analysis. The statistical package for social science -SPSS version 16 were used for analysis.

\section{Data Analysis and Discussion}

\subsection{Demographic Analysis}

Table 1. Age of the engineering college students

\begin{tabular}{|c|c|c|}
\hline Age & Frequency & Percentage \\
\hline 18 to 22 & 226 & 56.5 \\
\hline 23 to 27 & 130 & 32.5 \\
\hline Above 27 & 44 & 11.0 \\
\hline Total & 400 & 100.0 \\
\hline
\end{tabular}


Table 2. Gender of the engineering college students

\begin{tabular}{|c|c|c|}
\hline Gender & Frequency & Percentage \\
\hline Male & 232 & 58.0 \\
\hline Female & 168 & 42.0 \\
\hline Total & 400 & 100.0 \\
\hline
\end{tabular}

Table 3. Location of the engineering college students

\begin{tabular}{|c|c|c|}
\hline Location & Frequency & Percentage \\
\hline Urban & 254 & 63.5 \\
\hline Rural & 64 & 16.0 \\
\hline Semi-Urban & 82 & 20.5 \\
\hline Total & 400 & 100.0 \\
\hline
\end{tabular}

Table 4. Engineering College Student's Parent's Occupation

\begin{tabular}{|c|c|c|}
\hline Parent's Occupation & Frequency & Percentage \\
\hline Public sector & 137 & 34.3 \\
\hline Private sector & 87 & 21.8 \\
\hline Self-employed & 121 & 30.3 \\
\hline Retired & 30 & 7.5 \\
\hline Others & 25 & 6.3 \\
\hline Total & 400 & 100.0 \\
\hline
\end{tabular}

Table 5. Parent's Education Qualification

\begin{tabular}{|c|c|c|}
\hline Parent's Qualification & Frequency & Percentage \\
\hline SSLC & 8 & 2.0 \\
\hline HSC & 17 & 4.3 \\
\hline UG & 150 & 37.5 \\
\hline PG & 220 & 55.0 \\
\hline PHD & 5 & 1.3 \\
\hline Total & 400 & 100.0 \\
\hline
\end{tabular}

Table 6. Annual income of parents

\begin{tabular}{|c|c|c|}
\hline Parent's Annual Income & Frequency & Percentage \\
\hline Below 3L & 116 & 29.0 \\
\hline 3L-5L & 178 & 44.5 \\
\hline 6L-8L & 51 & 12.8 \\
\hline 9L-10L & 20 & 5.0 \\
\hline Above 10L & 35 & 8.8 \\
\hline Total & 400 & 100.0 \\
\hline
\end{tabular}

Table 7. Are you willing to take new business as a Job?

\begin{tabular}{|c|c|c|}
\hline Engineering Students opinion & Frequency & Percentage \\
\hline Yes & 237 & 59.3 \\
\hline No & 163 & 40.7 \\
\hline Total & 400 & 100.0 \\
\hline
\end{tabular}


The demographic profile of the respondents collected based on gender, age group, location, parent's occupation, parent's educational qualification, entrepreneurship questions, their close associates entrepreneurs and their interest in the entrepreneurial activity.

The above table 1 to 7 inferred that the dominance of male students. There are male students (58\%) and the female students (42\%) out of all the students. The most of the students falls between the age group of 18-22 and 23-27.The most of students parents are working in Public sector (34.3\%) and followed by self-employed parents. The most of the parents are PG Degree qualified (55\%) and followed by UG (37.5\%), The most of the parents annual income 3L to 5L (44.5\%) and followed by Below 3L (29\%) and maximum engineering students are willing to take new business as job (59.3\%).

\subsection{Chi-Square Test}

Table 8. Chi-Square Tests- Parents Occupations versus Parents guidance will help them to start their own business

Ho: There is no significant relationship between parents occupation versus Parents guidance will help them to start their own business

H1: There is a significant relationship between parents occupation versus Parents guidance will help them to start their own business

\begin{tabular}{|l|l|l|l|}
\hline & Value & df & Asymp. Sig. (2-sided) \\
\hline Pearson Chi-Square & $39.752(\mathrm{a})$ & 12 & .000 \\
\hline Likelihood Ratio & 40.540 & 12 & .000 \\
\hline Linear-by-Linear Association & .083 & 1 & .773 \\
\hline N of Valid Cases & 400 & & \\
\hline
\end{tabular}

a. 4 cells $(20.0 \%)$ have expected count less than 5 . The minimum expected count is 2.56 .

From the above table 8 In Pearson Chi-square value, were a low significance value of .000 (typically below 0.05) is observed. Hence, the Null hypothesis is rejected and alternative hypothesis is accepted and inferred that there exist a relationship between two variables namely parents occupation versus Parents guidance will help them to start their own business.

Table 9. Chi-Square Tests - Parents Occupations versus parent's occupation will control students new business to become self-employed

Ho: There is no significant relationship between parents occupation versus parent's occupation will control students new business to become self-employed

H1: There is a significant relationship between parents occupation versus parent's occupation will control students new business to become self-employed

\begin{tabular}{|l|l|l|l|}
\hline & Value & df & Asymp. Sig. (2-sided) \\
\hline Pearson Chi-Square & $58.427(\mathrm{a})$ & 16 & .000 \\
\hline Likelihood Ratio & 72.215 & 16 & .000 \\
\hline Linear-by-Linear Association & 15.469 & 1 & .000 \\
\hline N of Valid Cases & 400 & & \\
\hline
\end{tabular}

a. 7 cells $(28.0 \%)$ have expected count less than 5 . The minimum expected count is .06.

From the above table 9 In Pearson Chi-square value, were a low significance value of .000 (typically below 0.05) is observed. Hence, the Null hypothesis is rejected and alternative hypothesis is accepted and inferred that there exist a relationship between two 
variables namely parents occupation versus parent's occupation will control students new business to become self-employed.

Table 10. Chi-Square Tests - Parents Occupations versus only highly educated parents have more authority to support their graduate children to become an entrepreneur Ho: There is no significant relationship between parents occupation versus only highly educated parents have more authority to support their graduate children to become an entrepreneur

H1: There is a significant relationship between parents occupation versus only highly educated parents have more authority to support their graduate children to become an entrepreneur

\begin{tabular}{|l|l|l|l|}
\hline & Value & df & Asymp. Sig. (2-sided) \\
\hline Pearson Chi-Square & $47.904(\mathrm{a})$ & 12 & .000 \\
\hline Likelihood Ratio & 53.285 & 12 & .000 \\
\hline Linear-by-Linear Association & 8.018 & 1 & .005 \\
\hline N of Valid Cases & 400 & & \\
\hline
\end{tabular}

a. 4 cells $(20.0 \%)$ have expected count less than 5 . The minimum expected count is 3.88 .

From the above table 10 In Pearson Chi-square value, were a low significance value of .000(typically below 0.05) is observed. Hence, the Null hypothesis is rejected and alternative hypothesis is accepted and inferred that there exist a relationship between two variables namely parents occupation versus only highly educated parents have more authority to support their graduate children to become an entrepreneur.

\subsection{ANOVA and Multiple Comparisons Post-Hoc Bonferroni Test}

Table 11. ANOVA

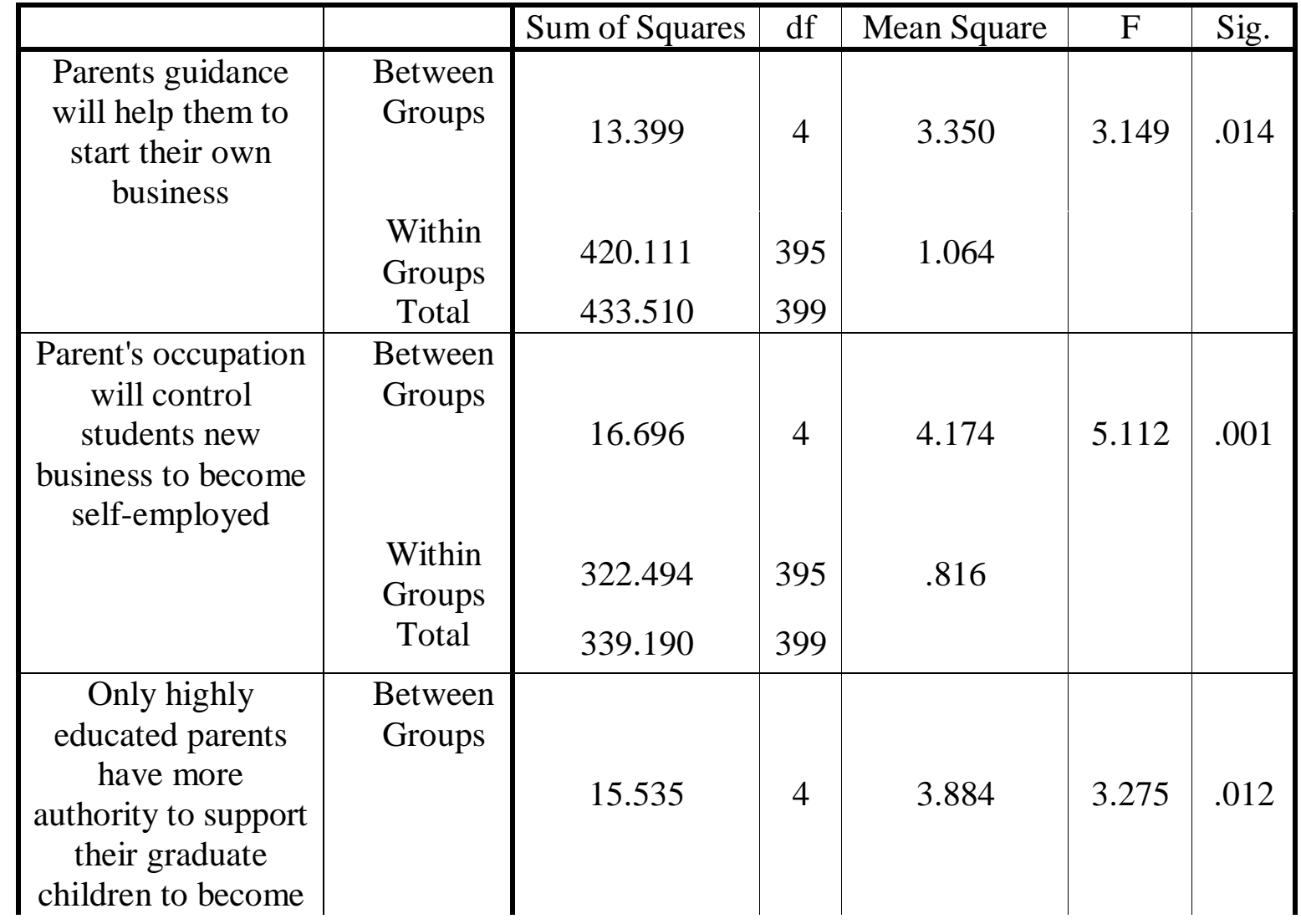




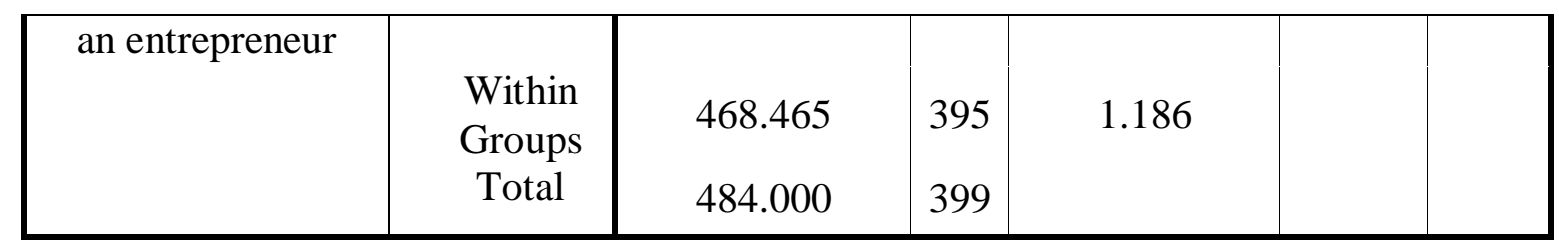

Table 12. Multiple Comparisons

Bonferroni

\begin{tabular}{|c|c|c|c|c|c|c|c|}
\hline \multirow[t]{2}{*}{$\begin{array}{l}\text { Dependent } \\
\text { Variable }\end{array}$} & \multirow[t]{2}{*}{$\begin{array}{l}\text { (I) 6. Parent's } \\
\text { Occupation }\end{array}$} & \multirow[t]{2}{*}{$\begin{array}{l}\text { (J) 6. Parent's } \\
\text { Occupation }\end{array}$} & \multirow[t]{2}{*}{$\begin{array}{c}\text { Mean Difference } \\
(\mathrm{I}-\mathrm{J})\end{array}$} & \multirow[t]{2}{*}{$\begin{array}{l}\text { Std. } \\
\text { Error }\end{array}$} & \multirow[t]{2}{*}{ Sig. } & \multicolumn{2}{|c|}{$\begin{array}{l}\text { 95\% Confidence } \\
\text { Interval }\end{array}$} \\
\hline & & & & & & $\begin{array}{l}\text { Lower } \\
\text { Bound }\end{array}$ & $\begin{array}{l}\text { Upper } \\
\text { Bound }\end{array}$ \\
\hline & Public sector & Private sector & -.049 & .141 & 1.000 & -.45 & .35 \\
\hline \multirow{19}{*}{$\begin{array}{l}\text { Parents guidance } \\
\text { will help them to } \\
\text { start their own } \\
\text { business }\end{array}$} & & Self-employed & -.244 & .129 & .590 & -.61 & .12 \\
\hline & & Retired & .472 & .208 & .238 & -.12 & 1.06 \\
\hline & & Others & -.175 & .224 & 1.000 & -.81 & .46 \\
\hline & Private sector & Public sector & .049 & .141 & 1.000 & -.35 & .45 \\
\hline & & Self-employed & -.195 & .145 & 1.000 & -.60 & .21 \\
\hline & & Retired & .521 & 218 & .176 & -.10 & 1.14 \\
\hline & & Others & -.126 & .234 & 1.000 & -.79 & .53 \\
\hline & Self-employed & Public sector & .244 & .129 & .590 & -.12 & .61 \\
\hline & & Private sector & .195 & .145 & 1.000 & -.21 & .60 \\
\hline & & Retired & $.715(*)$ & .210 & .007 & .12 & 1.31 \\
\hline & & Others & .069 & .227 & 1.000 & -.57 & .71 \\
\hline & Retired & Public sector & -.472 & .208 & .238 & -1.06 & .12 \\
\hline & & Private sector & -.521 & .218 & .176 & -1.14 & .10 \\
\hline & & Self-employed & $-.715(*)$ & .210 & .007 & -1.31 & -.12 \\
\hline & & Others & -.647 & .279 & .211 & -1.44 & .14 \\
\hline & Others & Public sector & .175 & .224 & 1.000 & -.46 & .81 \\
\hline & & Private sector & .126 & .234 & 1.000 & -.53 & .79 \\
\hline & & Self-employed & -.069 & 227 & 1.000 & -.71 & .57 \\
\hline & & Retired & .647 & .279 & .211 & -.14 & 1.44 \\
\hline \multirow{13}{*}{$\begin{array}{l}\text { Parent's } \\
\text { occupation will } \\
\text { control students } \\
\text { new business to } \\
\text { become self- } \\
\text { employed }\end{array}$} & Public sector & Private sector & & & & & \\
\hline & & Self-employed & -.292 & .113 & .099 & -.61 & .03 \\
\hline & & Retired & $-.749(*)$ & .182 & .000 & -1.26 & -.24 \\
\hline & & Others & -.416 & 197 & .349 & -.97 & .14 \\
\hline & Private sector & Public sector & .186 & .124 & 1.000 & -.16 & .54 \\
\hline & & Self-employed & -.106 & 127 & 1.000 & -.46 & .25 \\
\hline & & Retired & $-.563(*)$ & 191 & .034 & -1.10 & -.02 \\
\hline & & Others & -.230 & .205 & 1.000 & -.81 & .35 \\
\hline & Self-employed & Public sector & .292 & .113 & .099 & -.03 & .61 \\
\hline & & Private sector & .106 & .127 & 1.000 & -.25 & .46 \\
\hline & & Retired & -.457 & .184 & .135 & -.98 & .06 \\
\hline & & Others & -.124 & 199 & 1.000 & -.68 & .44 \\
\hline & Retired & Public sector & $.749\left(^{*}\right)$ & .182 & .000 & .24 & 1.26 \\
\hline
\end{tabular}




\begin{tabular}{|c|c|c|c|c|c|c|c|}
\hline & \multirow{7}{*}{ Others } & Private sector & $.563(*)$ & .191 & .034 & .02 & 1.10 \\
\hline & & Self-employed & .457 & .184 & .135 & -.06 & .98 \\
\hline & & Others & .333 & .245 & 1.000 & -.36 & 1.02 \\
\hline & & Public sector & .416 & .197 & .349 & -.14 & .97 \\
\hline & & Private sector & .230 & .205 & 1.000 & -.35 & .81 \\
\hline & & Self-employed & .124 & .199 & 1.000 & -.44 & .68 \\
\hline & & Retired & -.333 & .245 & 1.000 & -1.02 & .36 \\
\hline \multirow{20}{*}{$\begin{array}{l}\text { Only highly } \\
\text { educated parents } \\
\text { have more } \\
\text { authority to } \\
\text { support their } \\
\text { graduate children } \\
\text { to become an } \\
\text { entrepreneur }\end{array}$} & \multirow[t]{3}{*}{ Public sector } & Private sector & & & & & \\
\hline & & \multirow{2}{*}{$\begin{array}{l}\text { Self-employed } \\
\text { Retired }\end{array}$} & -.233 & .136 & .874 & -.62 & .15 \\
\hline & & & $-.660(*)$ & .220 & .028 & -1.28 & -.04 \\
\hline & \multirow{5}{*}{ Private sector } & Others & -.447 & .237 & .598 & -1.12 & .22 \\
\hline & & Public sector & .364 & .149 & .153 & -.06 & .79 \\
\hline & & Self-employed & .131 & .153 & 1.000 & -.30 & .56 \\
\hline & & Retired & -.297 & .231 & 1.000 & -.95 & .35 \\
\hline & & Others & -.083 & .247 & 1.000 & -.78 & .61 \\
\hline & \multirow[t]{4}{*}{ Self-employed } & Public sector & .233 & .136 & .874 & -.15 & .62 \\
\hline & & Private sector & -.131 & .153 & 1.000 & -.56 & .30 \\
\hline & & Retired & -.428 & .222 & .550 & -1.05 & .20 \\
\hline & & Others & -.214 & 239 & 1.000 & -.89 & .46 \\
\hline & \multirow[t]{4}{*}{ Retired } & Public sector & $.660(*)$ & .220 & .028 & .04 & 1.28 \\
\hline & & Private sector & .297 & .231 & 1.000 & -.35 & .95 \\
\hline & & Self-employed & .428 & .222 & .550 & -.20 & 1.05 \\
\hline & & Others & .213 & .295 & 1.000 & -.62 & 1.05 \\
\hline & \multirow[t]{4}{*}{ Others } & Public sector & .447 & .237 & .598 & -.22 & 1.12 \\
\hline & & Private sector & .083 & .247 & 1.000 & -.61 & .78 \\
\hline & & Self-employed & .214 & .239 & 1.000 & -.46 & .89 \\
\hline & & Retired & -.213 & .295 & 1.000 & -1.05 & .62 \\
\hline
\end{tabular}

*The mean difference is significant at the .05 level.

From the above table 2, it is inferred that in one-way ANOVA, Significance indicates the significance level of the F-test. Small significance value (<. 05) indicates group, the difference between variables namely parent's occupations and parents guidance will help them to start their own business(0.014), Parent's occupation will control students new business to become self-employed(0.001) and Only highly educated parents have more authority to support their graduate children to become an entrepreneur(0.012)

\subsection{Regression Analysis}

Table 13. Model Summary

\begin{tabular}{|c|c|c|c|c|}
\hline Model & $\mathrm{R}$ & R Square & $\begin{array}{l}\text { Adjusted R } \\
\text { Square }\end{array}$ & $\begin{array}{l}\text { Std. Error of the } \\
\text { Estimate }\end{array}$ \\
\hline 1 & $.435(\mathrm{a})$ & .189 & .187 & .845 \\
\hline
\end{tabular}

a. Predictors: (Constant), Parents support will help you to start own business 
The above table 13 displays are $\mathrm{R}, \mathrm{R} 2$, adjusted $\mathrm{R} 2$ and standard error $\mathrm{R}(. \mathrm{435})$ denotes the multiple correlation coefficient .i.e. it is the correlation between the observed and predicted values of the dependent variable. R2 (.189) is the proposition of variation in the dependent variable explained by the regression model. Sample R2 tends to optimistically estimates how well the model fits the population. Adjusted R2 (.187) attempts to correct R2 to more closely reflect the goodness of fit of the model in the population.

Table 14. ANOVA(b)

\begin{tabular}{|l|l|r|r|r|r|c|}
\hline Model & & $\begin{array}{c}\text { Sum of } \\
\text { Squares }\end{array}$ & df & Mean Square & F & Sig. \\
\hline & Regression & 66.011 & 1 & 66.011 & 92.480 & $.000(\mathrm{a})$ \\
\cline { 2 - 8 } & Residual & 282.662 & 396 & .714 & & \\
\cline { 2 - 8 } & Total & 348.673 & 397 & & & \\
\hline
\end{tabular}

a. Predictors: (Constant), Parents support will help you to start own business

b. Dependent Variable: [Overall, Family and parents guidance and support would create an best entrepreneur]

The above table 14 summarizes the results of the analysis of variance. Sum of squares, degrees of freedom, mean square are displayed for two sources of variations, regression and residual. The above output for regression displays information about the variations accounted for by the model. The output for a total (348.673) is the sum of information for regression (66.011) and residual (282.662). A model with the large regression sum of squares in comparison with residual sum of squares indicates that the model accounts for the most of the variation in the dependent variable. F statistics (92.480) are the regression mean square dividend residual mean squared. Regression degree of freedom is the numerated degree of freedom and the residual degree of freedom is the denominator degree of freedom for the ' $\mathrm{F}$ ' statistics. The total number degree of freedom is the number of cases minus 1 . If the significance of ' $F$ ' statistics is small (0.05), then the independent variable does a good work in explaining the variation in the dependent variable.

Table 15. Coefficients (a)

\begin{tabular}{|l|l|r|r|r|r|r|}
\hline $\begin{array}{l}\text { Mode } \\
1\end{array}$ & & \multicolumn{2}{|c|}{$\begin{array}{c}\text { Unstandardized } \\
\text { Coefficients }\end{array}$} & $\begin{array}{c}\text { Standardized } \\
\text { Coefficients }\end{array}$ & $\mathrm{t}$ & Sig. \\
\hline 1 & \multicolumn{1}{|c|}{$\mathrm{B}$} & \multicolumn{1}{c|}{$\begin{array}{c}\text { Std. } \\
\text { Error }\end{array}$} & Beta & & \\
\hline $\begin{array}{l}\text { (Constant) } \\
\begin{array}{l}\text { Parents support will } \\
\text { help you to start own } \\
\text { business }\end{array}\end{array}$ & 2.299 & .168 & & 13.671 & .000 \\
\hline
\end{tabular}

a. Dependent Variable: [Overall, Family and Parents guidance and support would create an best entrepreneur]

From the above table 15, Significance value .000 and beta value .435 and overall family and parents and support would create an best entrepreneur is the significant variables. 


\section{Conclusion and Implication}

In our present entrepreneurship atmosphere, positive parental factors in the direction of environment is a lot more value, it cannot be identified by some factors which promotes the positive parental aspects in the direction of our setting the design institution need to urge pupils to think about entrepreneurship as well as they will run their own company to have even more versatility in my individual and also domesticity and also they also can earn more cash by helping another person and they additionally need tiny seed grant or (start-up fund) would encourage entrepreneurship and they are seriously taken into consideration entrepreneurship as occupation alternative and it will certainly supply them earnings and it is too risky to begin their very own organization without any danger. The is reveal the growth of entrepreneurship over some years and it is highly interdisciplinary as well as heterogeneous and also their organizations have emerged to provide even more technology and the entrepreneurship has arisen in various area like, colleges, scientific research parks, incubators, commercial laboratories Muñoz-Bullón (2016) and we can likewise inclined trainees are much more cutting-edge, prepared to take dangers, very motivated, a lot more self-confident, with high internal locus of control however when it comes to a tolerance of uncertainty there is no distinction between likely as well as noninclined pupils Zaman (2013) The parents education and learning plays a vital role in positive perspective of an atmosphere, the students parents education ought to between 12th to UG so that the parents can motivate the students as well as provided trainees ideas about entrepreneurship environment. The engineering students specification likewise plays an essential function towards positive attitude of the environment, the pupils that are specialized in advertising and marketing and money are largely responsible for brand-new innovations, modern technologies and products and also trainees who are concentrated on human resource administration and also details system are have many suggestions for business endeavors and Info System pupils have much more service ideas. Out of all aspects of current research, the engineering students parents ought to encourage the trainees and also offer them extra ideas and also even more support towards entrepreneurship atmosphere and hence they can motivate and also sustain the development of university-based incubators and accelerators in collaboration with the economic sector, organizations as well as structures as well as Invest on building strong web visibility and likewise make use of social media, organic Google ranking (Search Engine Optimization), blog sites, informative websites/micro websites, and more. "Given that social media sites is such a hot topic in our company setting currently, it's something that every small business owner needs to a minimum of check out. 


\section{References}

Basu, A., \&Goswami, A. (1999). South Asian entrepreneurship in Great Britain: factors influencing growth. International Journal of Entrepreneurial Behavior \& Research, 5(5), 251-275.

Daim, T., Dabic, M., \& Bayraktaroglu, E. (2016). Students' entrepreneurial behavior: international and gender differences. Journal of Innovation and Entrepreneurship, 5(1), 19.

Gibcus, P., De Kok, J., Snijders, J., Smit, L., \& Van der Linden, B. (2012). Effects and impact of entrepreneurship programmes in higher education. Directorate-General for Enterprise and Industry, Brussels: European Commission.

Komulainen, K., Naskali, P., Korhonen, M., \&Keskitalo-Foley, S. (2014). Internal Entrepreneurship-a Trojan horse of the neoliberal governance of education? Finnish pre-and in-service teachers' implementation of and resistance towards entrepreneurship education. Journal for Critical Education Policy Studies, 9(1).

Küttim, M., Kallaste, M., Venesaar, U., \&Kiis, A. (2014). Entrepreneurship education at university level and students' entrepreneurial intentions. Procedia-Social and Behavioral Sciences, 110, 658-668.

Muñoz-Bullón, F. (2016). The State of Innovation and Entrepreneurship Research.

Thurik, R., \&Wennekers, S. (2004). Entrepreneurship, small business and economic growth. Journal of small business and enterprise development, 11(1), 140-149.

Rengiah, P. (2013). Effectiveness of entrepreneurship education in developing entrepreneurial intentions among Malaysian university students.

Zhou, M., \& Xu, H. (2012). A review of entrepreneurship education for college students in China. Administrative Sciences, 2(1), 82-98.

Zaman, M. (2013). Entrepreneurial characteristics among university students: Implications for entrepreneurship education and training in Pakistan. African Journal of Business Management, 7(39), 4053. 